based on a materialistic philosophy. The religious mysticism of pre-War Russia has now been replaced by the mysticism of the machine. The conception of science in Soviet Russia is that of an auxiliary to socialism. Education figures as a definite part of the Five Years Plan, and the Educational Plan comprises a general scheme of public education, the preparation of technicians and scientific workers from among the working classes, together with a general scheme of scientific research and the establishment of numerous scientific institutes. The author describes a number of these institutes which he visited, including the physico-technical "Kombinat" at Leningrad with its subsidiary institutes of physical chemistry and electro-physics. In addition, it has an experimental workshop of a unique character which manufactures scientific instruments for the "Kombinat" and other institutes. Employing about 300 workers, it is a half-industrial and halfscientific organisation. Soviet industry has thus behind it very extensive means for scientific research, and the various problems, classified according to interest or urgency, are investigated by the specialised chemical, physical or electrical institutes.

\section{Chemical Researches in Czechoslovakia}

Ever since the middle of last century, much chemical research work has been carried out at Prague. Some of the investigations, notably Prof. B. Brauner's work on atomic weights and on the rare earth elements, attracted wide attention, but much valuable, if less spectacular, work was overlooked. Few Czech men of science published in English journals; the majority of their researches appeared in the little-read Czech publications. To direct more attention to their achievements, Czechoslovak chemists founded in 1928 under the joint editorship of Profs. Votoček and Heyrovský the Collection of Czechoslovak Chemical Communications, in which the contributions were written in French or English. Among the more interesting contributions that have appeared recently in this journal mention may be made of the diseovery by Prof. Křepelka and Dr. Novotný that mercurous halides show marked triboluminescence, the actual intensity depending on the conditions of preparation. Prof. Simek has also made some observations on the curious electrical behaviour of fused tellurium dioxide. In organic chemistry, Drs. Landa and Machaček have described a new solid hydrocarbon, $\mathrm{C}_{10} \mathrm{H}_{16}$, to which they assign the name adamantane. A series of researches by Prof. Votoček and his collaborators has cleared up a number of points in connexion with the lesserknown sugars such as rhamnose, rhodeose and fucose. Prof. Heyrovský has also published a series of papers (referred to in NatuRE of March 10, p. 385) dealing with his polarographic studies with the dropping mercury cathode.

\section{The Indian Chemical Society (1924-1932)}

Prof. B. K. Singh's presidential address to the Indian Chemical Society (Journal of the Indian Chemical Society, vol. 10, No. 1, p. 1, 1933) deals with
"Optics in the Service of Chemistry", and includes a review of recent work on optical rotatory power and rotatory dispersion, to which he has himself con. tributed. He also records in a tabular form the growth of the Indian Chemical Society, during the nine years of its existence. During the first five years the growth was rapid, but the Society has held its own during the more difficult years from 1929 until 1932. It now includes 360 fellows and 100 subscribers, and is publishing approximately 100 papers in each year, of which 750 pages are printed free of cost by the University of Calcutta. Under these favourable conditions an income of about $10,000 \mathrm{Rs}$. has usually provided a credit balance, and a reserve fund of $21,000 \mathrm{Rs}$. has been built up, in addition to a donation of $10,000 \mathrm{Rs}$. from Sir P. C. Rây which is earmarked for the provision of a headquarters for the Society.

\section{Schlieren, Striæ or Streaks?}

IN the January issue of the Journal of Scientific Instruments, Mr. T. Smith, of the National Physical Laboratory, raises the question whether it is fair to Foucault to continue to describe the method he introduced for observing small optical differences of path by the name "schlieren" used for the method by Töpler in his paper of 1866 on the motion of singing flames. Messrs. Taylor and Waldram, who had used the term 'schlieren' in their paper in the December issue of the Journal, point out that Töpler in giving the method that name made no claim to its invention but only to an extension of the use of it to general scientific investigations. Would striæ or streaks be adequate equivalents of, and suitable alternatives for, schlieren?

\section{Uniformity in Bibliographical Particulars}

REFERRING to recent correspondence on this subject (Nature, 133, 380, March $10 ; 495$, March 31, 1934), Mr. A. Windelbandt, bibliographer in the library of the Institute of Plant Industry, Leningrad, writes pointing out the practical value of accurately given bibliographical citations in articles and books. Mr. Windelbandt states that footnotes and other references are often given in such a way as to make it impossible to recognise the publication. While the name of the author is quoted, the title of the article is often omitted and sometimes it is difficult to identify the journal owing to the manner in which the name is abbreviated. The absence of the year and volume in the case of articles, and the place of publication and name of publisher in the case of books, also renders it difficult for the reader to find the publication. Lack of pagination, too, may lead to a lengthy search, if a volume has no special index.

\section{Institute of Physics}

The annual general meeting of the Institute of Physics was held at the Royal Institution on May 15. After election of the officers and completion of the panel of the Board, it was announced that the following would take office on October 1 next: President, Sir Henry Lyons; Vice-President, Prof. W. L. Bragg ; Honorary Treasurer, Major C. E. S. 
Phillips; Honorary Secretary, Prof. J. A. Crowther ; New Members of the Board, Dr. Allan Ferguson and Mr. R. S. Whipple. In pursuance of one of the main objects of the Institute, namely, "to urge the import. ance of Physics in Industry", the Board has decided to arrange a two-day conference in the spring of 1935 on the applications of X-ray structural analysis to various industries. The main function of the conference will be to bring to the notice of industrialists what physics and physicists can do to help industry, rather than the discussion of technical matters among experts. The conference will be held in Manchester in conjunction with the local section of the Institute; and it is proposed to arrange an exhibition and visits in connexion with the meetings. Full details will be announced in due course.

\section{Ancient Chinese Books on Materia Medica}

IN the year A.D. 659, an illustrated volume of materia medica was published in China. It seems to have served until about 1061, when an extensive revision took place. Prof. Manzo Nakao has studied the history of this great compilation ("Notes on Shao-hsing Hsiao-ting Ching-shih Chêng-lei Pei-chi Pên-tsao (The Ancient Chinese Materia Medica Revised in the Sung Dynasty Shao-hsing period, 1131-1162)"'. J. Shanghai Sci. Inst. (3), 1, 1-9, May 1933). Much of the subject matter of the paper is of interest only to the Chinese historian, but some of the descriptions show that the work was very thorough, and covered at least 22 volumes. There were apparently several distinct revisions. The medicines can all be recognised; and the historical investigation was stimulated by the possibility of reviving some of the ancient remedies under modern conditions.

\section{"World List of Scientific Periodicals"}

THE second edition of the "World List of Scientific Periodicals" will be published in one volume by the Oxford University Press on June 30, at the price of $£ 33 s$., but subscribers in advance will receive it at $£ 22 s$. Such subscribers resident in Great Britain or Europe must post their cheques before June 30, or if outside Great Britain or Europe before July 30 . The new edition will contain titles and holdings of periodicals current right up to the end of 1933. The number of libraries the holdings of which are listed has been increased by 39 , the number being 189 as against 150. Approximately 10,000 new titles have been added, the total number of entries amounting to 36,380 . Each entry contains the title and place of publication of the periodical, the abbreviation, and the symbols for the libraries in which it is to be found and the dates of their holdings. Further information can be obtained from the Secretary, "World List of Scientific Periodicals", c/o The Zoological Society of London, Regent's Park, London, N.W.8.

\section{Announcements}

THe annual visitation of the National Physical Laboratory, Teddington, will be held on Tuesday, June 26, at 3-6 p.m.
THE annual visitation of the Royal Observatory, Greenwich, will be held on Saturday, June 2. The new 36 -in. reflecting telescope will be opened by the First Lord of the Admiralty at 3 p.m., and the Observatory will be open for inspection by invited guests at 3.30 p.m.

Prof. Lours Martin has been elected director of the Pasteur Institute of Paris in succession to the late Dr. Roux, with whom he had been closely associated.

Prof. J. BArcroft will deliver the Stephen Paget Memorial Lecture at the annual general meeting of the Research Defence Society at the London School of Tropical Medicine and Hygiene, Keppel Street, W.C.1, on June 5, at 3 p.m. The subject of Prof. Barcroft's lecture will be "Experiments on Man".

THE attention of chemists is directed by the Union Internationale de Chimie to the services rendered by the International Bureau of PhysicoChemical Symbols in placing at their disposal pure organic compounds the constants of which have been determined with great accuracy. The specimens supplied by the Bureau are guaranteed as possessing the constants of the values given in the published proceedings of the Bureau ( $J$. Chim. Phys., vols. $23,25,27,29$ and 31). They can be obtained at cost price from the Secretary of the Bureau, Prof. J. Timmermans, University, Brussels, from whom further information can be obtained.

The McGraw-Hill Publishing Co., Ltd., has issued its catalogue for 1934, containing a classified list of its books on agriculture, zoology and botany. The catalogue can be obtained post free from Aldwych House, London, W.C.2.

Applications are invited for the following appointments, on or before the dates mentioned:-An assistant in the Inquiry Bureau of the Building Research Station, Garston-The Secretary, Department of Scientific and Industrial Research, 16, Old Queen Street, Westminster, S.W.1 (May 30). A professor of botany at the University of St. Andrews -The Registrar (May 31). An assistant keeper of Oriental printed books and MSS. in the India Office Library-The Establishment Officer, India Office, Whitehall, S.W.I (June 1). A lecturer (woman) in mathematics (biology or botany subsidiary), at the Darlington Training College--The Principal (June 4). A lecturer in physics and elementary science at the City of Leeds Training College-The Director of Education, Education Department, Calverley Street, Leeds (June 5). A curator of the Museum and Art Gallery at Barking-The Town Clerk, Town Hall, Barking (June 7). An assistant agricultural organiser to the Northamptonshire County Council-The Secretary for Education, County Education Offices, Northampton (June 9). A professor of electrical technology at the Indian Institute of Science, Bangalore, India-The Director (Aug. I). A University professor of mining at Imperial College of Science and Technology-The Academic Registrar, University of London, S.W.7 (Jan. 14, 1935). 